\title{
Pathogenicity of nuclear polyhedrosis virus to Galleria mellonella L. (Lepidoptera: Pyralidae) and its control on stored beeswax foundations
}

\author{
Monir M. El Husseini@
}

\begin{abstract}
A nuclear polyhedrosis virus (GmMNPV) was isolated from the greater wax moth, Galleria mellonella L. (Lepidoptera: Pyralidae) larvae from a dead laboratory colony. A semi-synthetic diet was used for rearing G. mellonella at room conditions of $25-30{ }^{\circ} \mathrm{C}$ and $60-70 \%$ relative humidity. The polyhedral inclusion bodies (PIBs) of the virus were extracted and bio-assayed versus larvae of $\mathrm{L}_{3}$ of $\mathrm{G}$. mellonella in 5 concentrations, i.e., $2 \times 10^{2}, 2 \times 10^{3}, 2 \times 10^{5}, 2 \times$ $10^{7}$, and $2 \times 10^{8} \mathrm{PIBs} / \mathrm{ml}$ mixed in the diet $(1 \mathrm{ml}: 1 \mathrm{~g})$. Histopathological study was carried out through a light microscopy of 6-8 $4 \mathrm{~m}$ cross sections in larvae fed on diet contaminated with the virus $\left(2 \times 10^{8} \mathrm{PIBs} / \mathrm{ml}\right.$ in $1 \mathrm{~g}$ diet). The virus infected the nuclei in all organ cells of both ectodermal origins, e.g., hypoderm, tracheal epithelial cells, cells of salivary glands, epithelial cells of fore- and hindgut, and those of mesodermal origin, e.g., fat bodies and cortex of ganglia of the nervous system. Experimental protection of artificially infested beeswax foundations by spraying $\left(2 \times 10^{7} \mathrm{PIBs} / \mathrm{ml}\right)$ kept the wax foundations weight loss at $0.4 \%$ for 4 months storing, while those artificially infested without virus treatment were completely devoured (100\%) by larvae of the pest within 4 months due to successive pest generations. This treatment is recommended for protecting the stored beeswax foundations and combs as a safe alternative to the traditional hazardous chemical insecticides.
\end{abstract}

\section{Background}

Stored beeswax combs and wax foundations suffer economic damage by larvae of both the greater wax moth, Galleria mellonella L., and the small wax moth, Achroia grisella Fab., which can also infest wax combs in bee hives (Ibrahim et al. 1984). G. mellonella caused high destructive damage to beeswax combs in a very short time. Larvae feed not only on wax but they consume also bee cocoons, cast skins, and stored pollens beside spinning heavy silk galleries to live in. Infestation pollutes combs with larval debris and masses of webbings (Abou Bakr and El-Shemy 1991). Traditional control of these pests was concerned in the past by treatment of the stored

Correspondence: monirelhusseini45@gmail.com

Center of Biological Control \& IPM, Faculty of Agriculture, Cairo University, Giza, Egypt

SpringerOpen beeswax material with hazardous chemical pesticides like naphthalene, calcium cyanide, carbon dioxide, carbon tetrachloride, dichlorobenzeneethylen, and dibromide (Cantwell et al. 1972 and Morse 1980). Recently, the need for ecologically safer alternatives to the chemical insecticides drew the attention through the remarkable success of using entomopathogenic microorganisms in controlling many lepidopteran pest larvae with minimum or without harm to bees, natural enemies, animals, and human (Burges 1980, El Husseini 1981, Abou Bakr and El-Shemy 1991, Omar et al. 2004, Mansour et al. 2010, Metwally et al. 2011, and Essa et al.2015). The first nuclear polyhedrosis virus attacking an economic pest in Egypt was recorded by Abul Nasr (1956) in larvae of the cotton leaf worm, Spodoptera littoralis (Boisd.) (Prodenia litura F.), which successfully applied in the field (Abul Nasr 1959). Multi-embedded nucleopolyhedroviruses (MNPVs)

(c) The Author(s). 2020 Open Access This article is licensed under a Creative Commons Attribution 4.0 International License, which permits use, sharing, adaptation, distribution and reproduction in any medium or format, as long as you give appropriate credit to the original author(s) and the source, provide a link to the Creative Commons licence, and indicate if changes were made. The images or other third party material in this article are included in the article's Creative Commons licence, unless indicated otherwise in a credit line to the material. If material is not included in the article's Creative Commons licence and your intended use is not permitted by statutory regulation or exceeds the permitted use, you will need to obtain permission directly from the copyright holder. To view a copy of this licence, visit http://creativecommons.org/licenses/by/4.0/. 
of the family Baculoviridae proved highly effective in controlling many lepidopteran pest larvae under both laboratory and field conditions which were summarized early by Lacey et al. (2001) and recently by Grzywacz et al. (2017). Multi-embedded baculovirus species have a wide host range, and they are traditionally named after the insect species from which they were first isolated (Elangbam et al. 2016), such as SlMNPV isolated first from S. litura and Autographa californica MNPV (AcMNPV), Bombyx mori NPV (BmNPV), Lymantria dispar MNPV (LdMNPV), and the greater wax moth Galleria mellonella (GmMNPV) was first isolated from A. californica, B. mori, L. dispar, and G. mellonella, respectively. Host range of SlMNPV includes S. exigua, Trichoplusia, Autographa, Helicoverpa, B. mori, G. mellonella, and many other lepidopteran species (Elangbam et al. 2016). Previous cross infectivity tests of Mudasir et al. (2014) support the wide host range of MNPVs. The remarkable success of baculoviruses as biological agents lets Thézé et al. (2018) call them "A treasure trove for future applied research". That the sun ultra violet rapidly inactivated the baculoviruses applied on crops in the open fields (Elnagar et al. 2003), this factor is absent indoors at the stores. Aim of the present study is to investigate the pathogenicity of a nuclear polyhedrosis virus (GmMNPV) isolated from dead larvae of G. mellonella and its pathogenicity and efficacy in controlling this pest on stored wax foundation sheets.

\section{Material and methods}

\section{G. mellonella larvae}

A colony of G. mellonella was reared for many years at the Center of Biological Control, Faculty of Agriculture, Cairo University, Egypt, as model insect for different traditional biological control and microbial control research studies. The larval colony was reared on the semi-synthetic diet described by Ibrahim et al. (1984) and Metwally et al. (2012). The diet consisted of two components; the first is in dry powdered form containing $20 \mathrm{~g}$ corn flour, $10 \mathrm{~g}$ milk powder, and $90 \mathrm{~g}$ wheat flour, and the second in fluid form of $20 \mathrm{ml}$ bee honey and $20 \mathrm{ml}$ glycerin. The dry components were wellmixed together, and the two fluids together. Then, the mixed fluids were added gradually to the dry mixed components with continuous mixing to reach a wetted paste that could be kept frozen till needed. The diet was placed in metal boxes $(14 \times 30 \times 15 \mathrm{~cm})$ because the wax moth larvae chew the plastic containers. A diet layer of $8-10-\mathrm{cm}$ height was placed into the metal boxes, and eggs of G. mellonella were placed on a piece of paper on the diet surface. The boxes were covered by perforated metal cover top and held in the rearing room at 25$30{ }^{\circ} \mathrm{C}$ and $60-70 \%$ relative humidity. The rearing room was well equipped with ventilators to keep the temperature under $30{ }^{\circ} \mathrm{C}$ due to the raised temperature of the rearing boxes caused by the developing larvae inside. Formed pupae attached to the rearing box cover top were collected and transferred to a wooden cage of $50 \times 50 \times 50 \mathrm{~cm}$ with glass sides and a cloth sleeve door. Emerged adults were collected through the sleeve door with a small electric hover and placed in groups of ca 30 adult moths in 2-1 glass containers and covered with a piece of paper secured in place by a rubber band. Females laid eggs mostly on the cover paper which was replaced daily, and the laid egg clusters attached to the paper were cut using a scissor and placed on diet in new boxes. The colony provided the needed numbers of larvae in the desired instar for the tests.

\section{G. mellonella virus (GmMNPV)}

A sudden death of larvae in some rearing boxes revealed typical symptoms of developed infection by a nuclear polyhedrosis virus. Koch's postulates were applied and proved death of larvae by GmMNPV. Following the technique described by Parthasarathy and Rabindra (2002), the cadavers of larvae were macerated and homogenized in sterilized distilled water, and the crude was passed for primary filtration through several layers of muslin cloth. To remove the debris from the filtrate, it was centrifuged at $900 \mathrm{rpm}$ for $2 \mathrm{~min}$, and the supernatant was further centrifuged at $5000 \mathrm{rpm}$ for $10 \mathrm{~min}$. The pellet of polyhedral inclusion bodies (PIBs) was resuspended in sterile distilled water for adjusting to $2 \times$ $10^{8} \mathrm{PIBs} / \mathrm{ml}$ using a hemocytometer and kept in a refrigerator at $4{ }^{\circ} \mathrm{C}$ till needed for the tests.

\section{Bioassay of GmMNPV versus G. mellonella larvae $\left(\mathrm{L}^{3}\right)$}

Five concentrations from GmMNPV at $2 \times 10^{2}, 2 \times 10^{3}$, $2 \times 10^{5}, 2 \times 10^{7}$, and $2 \times 10^{8} \mathrm{PIBs} / \mathrm{ml}$ were prepared in sterilized distilled water. One milliliter of each concentration was mixed in 1-g diet and spread in a thin layer in glass Petri dish $(5 \mathrm{~cm}$ in diameter). Ten larvae at the 3rd instar $\left(\mathrm{L}_{3}\right)$ were placed on the spread diet and left feeding on for $24 \mathrm{~h}$; thereafter, they were transferred onto untreated diet and inspected daily. The treatments were replicated 4 times using 50 larvae each. A control was set in the same manner on untreated diet. Mortality among treatments and control was recorded daily for 10 days post-treatment. The test larvae originated from a new colony reared from disinfected eggs of G. mellonella on the same diet in disinfected metal containers to ensure that they were healthy and not infected with the virus.

\section{Histopathological features}

Larvae of G. mellonella fed on diet treated with GmMNPV $\left(2 \times 10^{8} \mathrm{PIBs} / \mathrm{ml}\right.$ in $1 \mathrm{~g}$ diet $)$ were picked up at the 5th and 7th day post-treatment and fixed in Buin's fixative. Fixed larvae were rinsed in $70 \%$ ethyl alcohol for 
$6 \mathrm{~h}$ and dehydrated in ascending ethyl alcohol concentrations of $80,90,95$, and $100 \%$ each for $5 \mathrm{~h}$, followed by clearing in xylene for $12 \mathrm{~h}$ and transferred in xylene: paraffin wax 2:1, 1:1, and two times each for $12 \mathrm{~h}$ in pure paraffin wax at $40^{\circ} \mathrm{C}$. The wax-impregnated larvae were poured in blocks over iced water and trimmed for cross serial sectioning by microtome at $6-8$ microns. The serial sections were glued on glass slides by Mayer' Albumin and left on a hot plate $\left(30^{\circ} \mathrm{C}\right)$ for adhering. The wax was removed by washing two times each for $20 \mathrm{~min}$ in xylene. The sections adhered to the slides were hydrated in descending ethyl alcohol concentrations of $100,95,90,80$, and $70 \%$ each for $15 \mathrm{~min}$ and stained either with eosin or hematoxylin and then, dehydrated in ascending ethyl alcohol from 70 to $100 \%$ and cleared in xylene before mounting in Canada Balsam and dried at $40{ }^{\circ} \mathrm{C}$ for 3 days. The prepared cross sections were examined by light microscope connected to a computer for photography to show the polyhedral inclusion bodies of the virus in cells of different tissues and disintegrated cell contents in the body cavity of the infected larvae.

\section{Control of G. mellonella on stored wax foundations by GmMNPV}

The possibility for controlling larvae of the wax moth using GmMNPV $\left(2 \times 10^{7} \mathrm{PIBs} / \mathrm{ml}\right)$ on stored wax foundations was tested. Twenty sheets of beeswax foundations previously sterilized by formalin vapor were sprayed by the virus concentration using a hand atomizer each on both sides and left standing vertically for evaporation of the sprayed water leaving the PIBs on the wax behind. Thereafter, they were placed horizontally, and each received ca 200 eggs of G. mellonella and left for 6 days to enable the newly hatched larvae to start feeding and settle themselves on the wax sheets. The treated wax sheets were stored vertically in a wooden box at room temperature of $25-30{ }^{\circ} \mathrm{C}$ and $60-70 \% \mathrm{RH}$. Another surface-sterilized 20 wax sheets were sprayed only with distilled water and received ca 200 eggs of $G$. mellonella served as control. The infested wax sheets harboring the larvae were planned to store for 12 months and were weighted together monthly, and the loss percent was calculated. A blank control of the healthy larvae without treatment was set up, and the wax foundations were kept in similar wooden box under the same storing conditions.

\section{Results and discussion}

\section{Bioassay of GmMNPV versus $G$. mellonella larvae $\left(L_{3}\right)$}

Feeding larvae of $G$. mellonella in $\mathrm{L}_{3}$ on diet contaminated with five different concentrations of the virus GmMNPV resulted in different mortality values started at the 6th day after ingestion as presented in Table 1. The 1st treatment $\left(\mathrm{T}_{1}\right)$ with the lowest tested
Table 1 Mortality percent among larvae $\left(L_{3}\right)$ of $G$. mellonella on diet treated with different concentrations of GmMNPV

\begin{tabular}{lllllllllll}
\hline GmMNPV & \multicolumn{7}{c}{ Mortality $\%$ among } & 7 days after treatment & & \\
\cline { 2 - 9 } $\begin{array}{l}\text { concentration } \\
\text { (PIBs/ml) }\end{array}$ & 1 & 2 & 3 & 4 & 5 & 6 & 7 & 8 & 9 & 10 \\
\hline $2 \times 10^{2}$ & 0 & 0 & 0 & 0 & 0 & 0 & 60 & 78 & 89 & 96 \\
$2 \times 10^{3}$ & 0 & 0 & 0 & 0 & 0 & 0 & 64 & 70 & 78 & 82 \\
$2 \times 10^{5}$ & 0 & 0 & 0 & 0 & 0 & 0 & 88 & 90 & 100 & \\
$2 \times 10^{7}$ & 0 & 0 & 0 & 0 & 0 & 0 & 90 & 100 & & \\
$2 \times 10^{8}$ & 0 & 0 & 0 & 0 & 0 & 0 & 92 & 100 & & \\
Control & 0 & 0 & 0 & 0 & 0 & 0 & 0 & 0 & 0 & 0 \\
\hline
\end{tabular}

concentration $\left(2 \times 10^{2} \mathrm{PIBs} / \mathrm{ml}\right)$ induced the lowest recorded larval mortality $(60 \%)$ at the 7 th day posttreatment, that slightly increased to 78,89 , and $96 \%$ at 8th, 9th, and 10th days, respectively. Increasing the virus concentration in the second treatment $\left(\mathrm{T}_{2}\right)$ to $2 \times 10^{3}$ $\mathrm{PIBs} / \mathrm{ml}$ elevated the mortality value to $64 \%$ starting also at the 7th day post-treatment which increased among the next 3 days to reach $82 \%$ at the 10th day. Further increase in the ingested concentrations at the treatments $\mathrm{T}_{3}, \mathrm{~T}_{4}$, and $\mathrm{T}_{5}\left(2 \times 10^{5}, 2 \times 10^{7}\right.$, and $2 \times 10^{8} \mathrm{PIBs} / \mathrm{ml}$, respectively) induced death in treated larvae at the 7 th day by 88,90 , and $92 \%$, respectively; and reached the $100 \%$ mortality at the 8 th and 9th days after treatment. Further mortality increase in the 8th, 9th, and 10th days reached $100 \%$ for the 3 highest tested concentrations (Table 1). Meanwhile, no mortality occurred among larvae of the control till end of the test; thus, corrected mortality values in the treatments were not necessary to calculate.

\section{Histopathological features}

Infected G. mellonella larvae subjected to histopathological study 6 and 7 days after ingesting the contaminated diet with the virus GmMNPV at a concentration of $2 \times 10^{8} \mathrm{PIBs} / \mathrm{ml}$ proved the infection and replication of the virus in all tissues of ecto- as well as of mesodermal origin. The virus infected nuclei of all the hypodermal cell layer showing them filled with the polyhedral inclusion bodies (PIBs) before rupturing of the nucleic membrane as seen in Fig. 1a and those of the fat body (Figs. $1 \mathrm{~b}$ and $2 \mathrm{a}$ ). The nuclei of the tracheal epithelial cells were also infected as site of virus replication showing the PIBs scattered in the cell cytoplasm after rupturing of the nucleic membrane (Fig. 1c and d). Mesodermaloriginated tissues as gonads and nerve cells were infected, and the virus replicated in their cell nuclei as shown in Fig. 2c and d, respectively. Finally, all organs in the body of the infected larva were dissolved turning into a fluid full with PIBs except the chitinous structures, i.e., the body cuticle and the tenidium of the respiratory trachea that left unchanged as seen in Fig. 3b. Such alterations started first 


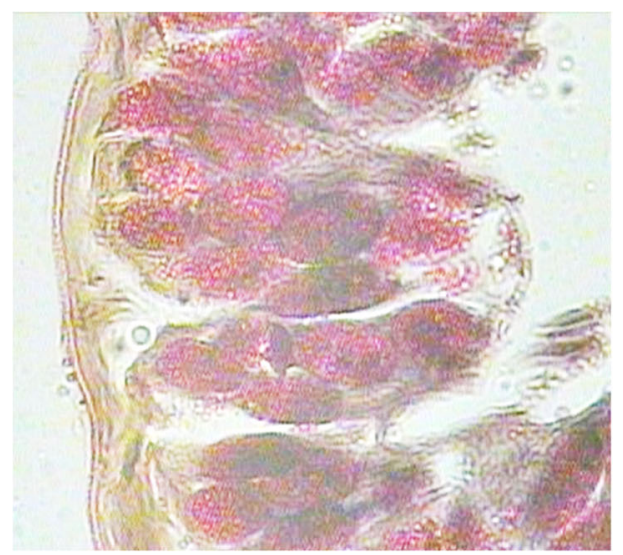

A

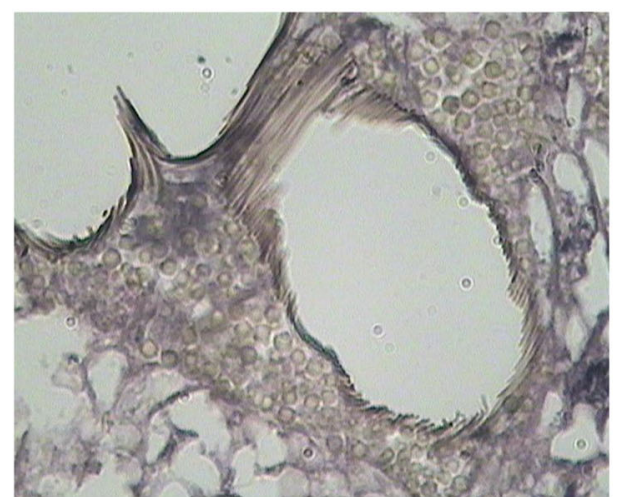

$\mathrm{C}$

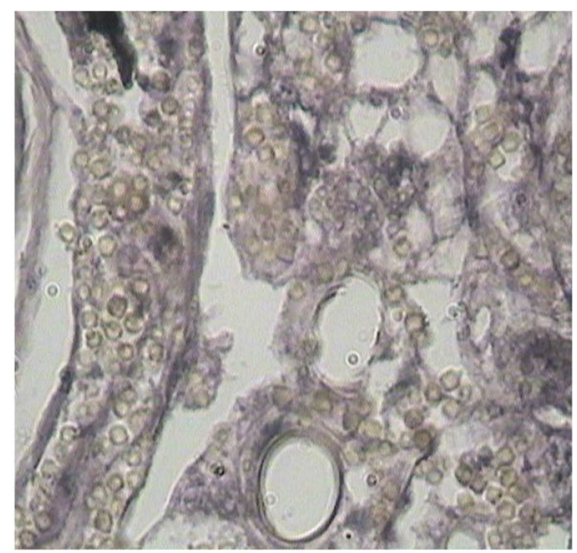

$\mathrm{B}$

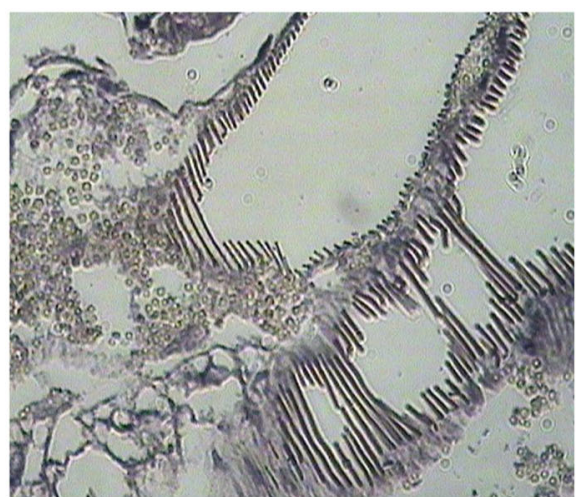

$\mathrm{D}$

Fig. 1 Cross sections in Galleria mellonella larvae 6 days post-infection with GmMNPV. a PIBs filling the nuclei of hypodermal cells under the body cuticle. $\mathbf{b}$ PIBs in nuclei of fat body cells. $\mathbf{c}$ and $\mathbf{d}$ PIBs in epithelial cells of the trachea

in midgut epithelial cells causing feeding stop. As well, motionless due to infection of the nerve cells and alterations in tracheal epithelial cells lower and stop respiration leading to death of infected larvae. These results are in line with similar studies with MNPVs in larvae of different lepidopteran species, like those of El Husseini (1980) in Spodoptera exigua, Yan and Li (1991) in Dendrolimus spectabilis, Daibin et al. (1999) in Zethenia rufescentaria, Barreto et al. (2005) in Spodoptera frugiperda, and Wang et al. (2017) in Bombyx mori and Belda et al. (2019).

\section{Control of G. mellonella on stored wax foundations by GmMNPV}

Results indicated weight loss in treated beeswax foundations with GmMPNV at the concentration of $2 \times 10^{7}$ $\mathrm{PIBs} / \mathrm{ml}$; the loss reached $0.4 \%$ after 1 month and remained stable among the next 3 months. This result could be explained by feeding of the newly hatched wax moth larvae on the treated wax sheets acquiring infection with the virus PIBs which developed in and caused their death. Accordingly, the infestation was stopped by eliminating the pest. Meanwhile, the pest larvae fed on non-treated wax foundations caused $18 \%$ weight loss after 1 month. Producing successive generations of the pest along the following storing period generated further losses reaching 48 and $82 \%$ after 2 and 3 months, respectively. A complete loss of the wax foundations (100\%) occurred after storing for 4 months. The clean blank control remained unchanged in weight along the period of the test which is shortened to 4 months instead of the planned 12 months. These results are in line with those of Abou Bakr and El-Shemy (1991). Omar et al. (2004) reported $100 \%$ loss in weight of wax foundations artificially infested with eggs of G. mellonella after 10 months storing as opposed to $0 \%$ in those sprayed by Dipel 2X (Bacillus thuringiensis kurstaki). Results of the present study and those of other authors (e.g., Abou Bakr and El-Shemy 1991, Lacey et al. 2001, Omar et al. 2004) confirmed the success of microbial control with baculoviruses, and B. thuringiensis in stores against larvae of the greater wax moth may be due to its high sensitivity to both entomopathogens, in addition to absence of sunlight UV in the stores. 


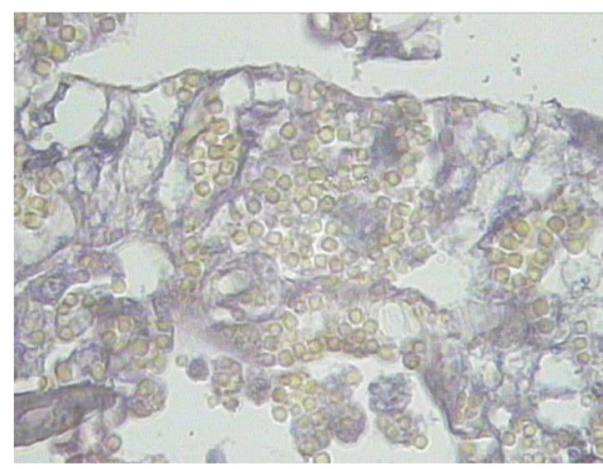

A

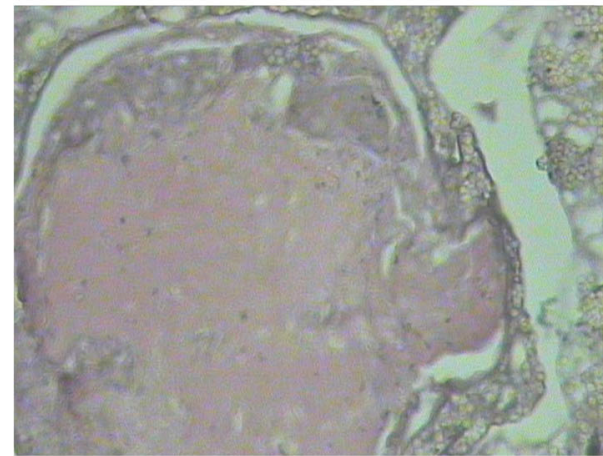

$\mathrm{C}$

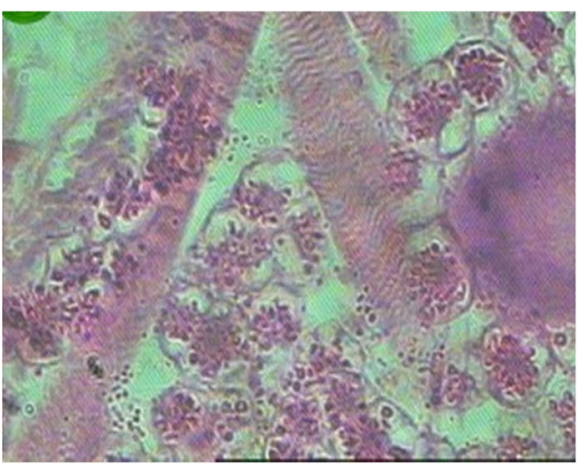

$\mathrm{B}$

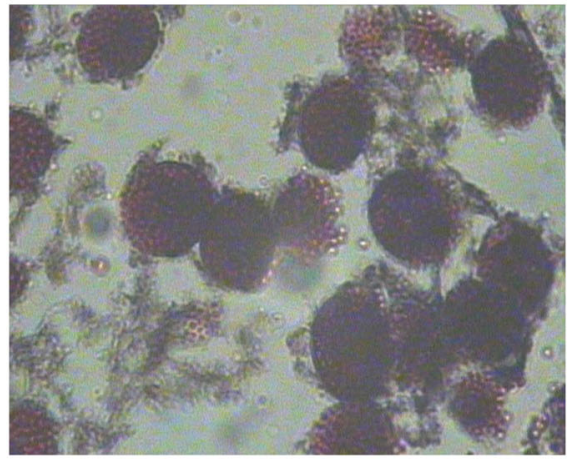

$\mathrm{D}$

Fig. 2 Cross sections in Galleria mellonella larvae 6 days post-infection with GmMNPV. a and $\mathbf{b}$ PIBs in nuclei of the fat body. $\mathbf{c}$ PIBs in nuclei of cortex cells of a nerve ganglion. $\mathbf{d}$ PIBs in nuclei of disintegrated tissue cell prior to rupture of nucleic membrane

\section{Conclusion}

Bio-assaying virulence of G. mellonella nuclear polyhedrosis virus (GmMNPV) versus $\mathrm{L}_{3}$ larvae of Galleria mellonella proved a high pathogenicity to this pest; in other words, the larvae of G. mellonella are highly susceptible to the virus. This fact was confirmed when applying the virus by spraying its PIBs onto the beeswax foundations followed by high artificial infestation with eggs of the pest before storing. The treatment protected the wax foundations for many months in the store. Thus, using entomopathogenic baculoviruses for protecting stored combs and beeswax foundations seems an effective alternative to the traditional use of the hazardous chemical pesticides for this purpose.

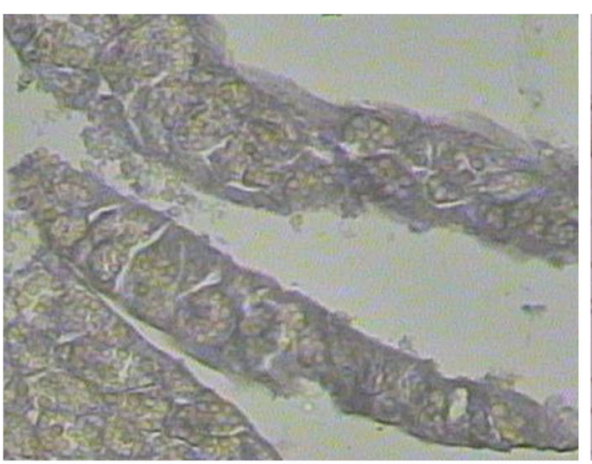

A

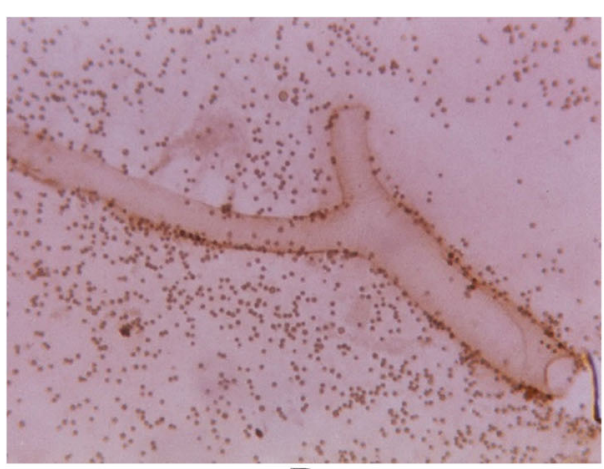

B

Fig. 3 Cross sections in Galleria mellonella larvae. a Six days post-infection with GmMNPV showing PIBs in nuclei of salivary gland epithelial cells. b Smear of body fluid from G. mellonella larva at 7th day post-treatment showing complete disintegration of body cells except the chitinous tenidium of the trachea 


\section{Abbreviations}

GmMNPV: Galleria mellonella multi nuclear polyhedrosis virus; PIBs: Polyhedral inclusion bodies; $L_{3}$ : $3 r d$ larval instar; $T_{1}$ : Treatment with the virus concentration $2 \times 10^{2} \mathrm{PIBs} / \mathrm{ml} ; \mathrm{T}_{2}$ : Treatment with the virus concentration 2 $\times 10^{3} \mathrm{PIBS} / \mathrm{ml}^{\prime} \mathrm{T}_{3}$ : Treatment with the virus concentration $2 \times 10^{5} \mathrm{PIBs} / \mathrm{ml}$ $\mathrm{T}_{4}$ : Treatment with the virus concentration $2 \times 10^{7} \mathrm{PIBs} / \mathrm{ml} ; \mathrm{T}_{5}$ : Treatment with the virus concentration $2 \times 10^{8} \mathrm{PIBs} / \mathrm{ml}$

\section{Acknowledgements}

Not applicable

\section{Authors' contributions}

The author declares that he carried out the research study, analyzed the data and wrote the manuscript. The author(s) read and approved the final manuscript.

\section{Funding}

Not applicable

\section{Availability of data and materials}

Not applicable

\section{Ethics approval and consent to participate}

Not applicable

\section{Consent for publication}

Not applicable

\section{Competing interests}

The author declares that he has no competing interests.

Received: 7 April 2020 Accepted: 21 July 2020

Published online: 05 August 2020

\section{References}

Abou BH, El-Shemy AAM (1991) Use of Bacillus thuringiensis for protection of bee wax combs against Galleria mellonella L. Egypt J Appl Sci 6(12):121-131

Abul NS (1956) Field tests on the use of a polyhedrosis virus disease for control of the cotton leaf worm, Prodenia litura F. Bull Soc Ent Egypté 40:321-332

Abul NS (1959) Further tests on the use of a polyhedrosis virus in the control of the cotton leaf worm, Prodenia litura F. J Insect Pathol 1:112-120

Barreto M.R., Guimaraes C.T., Teixeira F.F., Paiva E., Valicente F.H. 2005. Effect of Baculovirus spodoptera isolates in Spodoptera frugiperda (J.E. Smith) (Lepidoptera: Noctuidae) larvae and their characterization by RAPD, Neotropical Entomology, 34(1), 67-75.

Belda Ml, Beperet I, Williams T, Caballero P (2019) Genetic variation and biological activity of two closely related alphabaculoviruses during serial passages in permissive and semi-permissive heterologous hosts. Viruses 11(7):660

Burges HD (1980) Safety testing and quality control: in Microbial control of pests and plant diseases, 1970-1980. Academic Press, London, 949 pp

Cantwell GE, Jay EG, Pearman JC, Thompson JV (1972) Control of the greater wax moth Galleria mellonella L. in comb honey with carbon dioxide. Amer Bee 112(8):302-303

Daibin L, Wang Z, Hua Y, Hu X, Huang X, Xie S, Liu J, Luan X, Mu Z (1999) Study on histopathology of nuclear polyhedrosis virus of Zethenia rufiscentaria Motsh. J Forst Res 10:51-54

El Husseini M.M.1980. A nuclear polyhedrosis virus inducing cellular hypertrophy in larvae of Spodoptera exigua (Hb.). Proc.1 1st Conf. Plant Protection Inst., Vol. II, pp. 405-419.

El Husseini M.M. 1981.New approach to control the cotton leaf worm, Spodoptera littoralis (Boisd.) by Bacillus thuringiensis Berliner in clover fields.Bull ent Soc Egypt Econ Ser, 12: 1-6.

Elangbam BD, Elangbam PD, Deepshikha A (2016) An overview on nucleopolyhedrosis virus (NPV) as a valuable biopesticide in enhancing ecofriendly management of insect pests. International Journal of Current Research in Biosciences and Plant Biology 3(8):97-106

Elnagar S, El-Sheikh MAK, El-Salamouny S, Amin A, Khattab M (2003) Screening of four lignin additives as UV protectants to baculoviruses. Bull ent Soc Egypté, Econ Ser 29:165

Essa NM, El Sherif HA, Abdel Aziz NM (2015) Effects of Bacillus thuringiensis and nuclear polyhedrosis virus on some biological aspects and metamorphosis of the cotton leaf worm, Sposoptera littoralis (Boisd.). Egypt J Biol. Pest Control 25(2):463-469

Grzywacz D (2017) In: Lacey LA (ed) Basic and applied research: baculovirus. In Microbial control of insect and mite pests: from theory to practice. Academic Press: Cambrige, MA, USA, pp 27-46

Ibrahim SH, Ibrahim AA, Fayad YH (1984) Studies on mass rearing of the wax moth, Galleria mellonella L. and its parasite, Apanteles galleriae W. with some biological notes on the parasite. Agric Res Rev 62(1):349-353

Lacey LA, Frutos R, Kaya HK, Vail P (2001) Insect pathogens as biocontrol agents: do they have a future? Biol Cont 21:230-248

Mansour HM, Sanad RE, Saad IA (2010) Biological and chemical control of the lepidopterous wax moths. Galleria mellonella and Ashroia grissella Feb. infesting bee wax in storage. Egyptian Journal of Biological Pest Control 20: 55-59

Metwally HMS, Hafez GA, Hussein MA, Salem HA, Saleh MME (2012) Low cost artificial diet for rearing the greater wax moth, Galleria mellonella $\mathrm{L}$. (Lepidoptera: Pyralidae) as a host for entomopathogenic nematodes. Egypt J Biol Pest Control 22(1):15-17

Morse R.A. 1980. Honey bee pest, predators and diseases. Cornell University Press, UK pp. 105-124.

Mudasir G, Gupta RK, Bali K (2014) Efficacy of Spodoptera litura multiple nucleopolyhedrovirus after serial passages through the homologous insect larval host. Indian Journal of Experimental Biology 52:369-374

Omar NAM, El Husseini MM, El Bishry MH (2004) The use of Bacillus thuringiensis kurstaki in protecting stored bee wax combs and wax foundations against the greater wax moth larvae, Galleria mellonella L. Egypt J Biol Pest Control 14(2):415-418

Parthasarathy R, Rabindra RJ (2002) Cross infectivity of Galleria mellonella nuclear polyhedrosis virus (GmMNPV) to several economically important lepidopteran insect pests. Pest Management in Horticulture Ecosystem 18(2): 115-119

Thézé J, Lopez-Vaamonde C, Cory JS, Herniou EA (2018) Biodiversity, evolution and ecological specialization of baculoviruses: a treasure trove for future applied research. Viruses 10:366

Wang L, Qin X, Zhou X, Zhu Y, Dong Z, Chen P, Pan M, Lu C (2017) Bombyx mori nuclear polyhedrosis virus (BmNPV) induces host cell autophagy to benefit infection. Viruses 10(1):14

Yan Z, Li S (1991) Study on the structure and tissue pathology of nuclear polyhedrosis virus of Dendrolimus spectabilis. Insect-Kill Microorganism 3:137-140

\section{Publisher's Note}

Springer Nature remains neutral with regard to jurisdictional claims in published maps and institutional affiliations.

\section{Submit your manuscript to a SpringerOpen ${ }^{\circ}$ journal and benefit from:}

- Convenient online submission

- Rigorous peer review

- Open access: articles freely available online

High visibility within the field

- Retaining the copyright to your article

Submit your next manuscript at $\boldsymbol{\nabla}$ springeropen.com 